\title{
An Examination of Legislature-Executive Crisis under the APC Led Democratic Governance in Nigeria's Fourth Republic and Its Impact on Good Governance, 2015-2019
}

\author{
Victor Vincent Okpe* and Muhammad Fuad Othman \\ Asian Institute of International Affairs and Diplomacy, College of Law, Government and International Studies, \\ Universiti Utara Malaysia, 06010 Sintok, Kedah, Malaysia
}

\begin{abstract}
This study examined the legislature-executive crisis in Nigeria under the APC- led democratic governance between 2015 and 2019. The objective was to understand the factors that animated the crisis and its implication on good governance. To achieve this, the study relied on the descriptive qualitative approach and the institutional theory of conflict to create linkage and consolidate the findings. It used mainly secondary data like textbooks, journal articles, legislature-executive documents, and the 1999 Nigerian Constitution. From the analysis, several factors emerged which included leadership interference and parliamentary oversight. Others were poor capacity building, corruption, and absence of enough communication. By implication, the result showed that between 1999 and 2015, the parliament passed 248 bills into law, but passed 213 bills between

ARTICLE INFO

Article history:

Received: 14 February 2021

Accepted: 15 May 2021

Published: 30 June 2021

DOI: https://doi.org/10.47836/pjssh.29.2.34

E-mail addresses:

Victorenugu47@gmail.com (Victor Vincent Okpe) mfuad@uum.edu.my (Muhammad Fuad Othman) *Corresponding author

2015 and 2019. However, information also appeared that the crisis impacted more negatively on the institutions' relations and the political system. It disrupted the democratic ethics of accountability, transparency, and equitable distribution of resources. Public policies like lawmaking, oversight and implementation suffered greatly. Unnecessarily delayed budget proposals increased poverty, economic deprivation, and instability. Positive changes promised by the APC government were
\end{abstract}


lost in the crisis and these were all against democratic ethos. Based on the ongoing, the study concluded that democracy and good governance can be strengthened when the institutions collaborate better to execute their roles, respect their institutions and the 1999 Constitution. The study would benefit the institutions, the public and researchers. Further study is also needed on the judiciary-legislature pattern of relations under Nigeria's fourth republic democratic governance.

Keywords: Democracy, fourth republic, good governance, legislature-executive crisis, Nigeria

\section{INTRODUCTION}

In a presidential democracy, the place of the legislature and the executive cannot be overemphasized. They are instruments of good governance and democratic consolidation (Godswealth et al., 2016; Momodu, 2012; Momodu \& Matudi, 2013; Oni, 2014; Osakede et al., 2017). In Nigeria, for instance, the return of presidential democracy in 1999 after many years of military rule, brought positive expectations to the people (Egbefo, 2015; Ogbo \& Avidime, 2016; Oni, 2014; Yusuf, 2018). This was because it brought back civil rule, a multi-party system and the legislature as the mouthpiece of the public. Separation of powers and roles between the legislature, the executive as well as the judiciary were also defined. However, and important to note, after several decades of democratic experiment and the conduct of elections, the authors added that the positive expectations of the citizens were dashed. They became affected by poor governance, corruption, institutional weakness, instability, and conflicts. According to Oni (2014), the political system has failed to be stable for good governance and democratic consolidation, and the pattern of legislatureexecutive relations remains most disturbing.

Accordingly, scholarly literature also argued that one of the foremost factors threatening democracy and good governance in Nigeria is the form of interaction between the executive and the legislature (Godswealth et al., 2016; Momodu \& Matudi, 2013; Okon et al., 2013). In the 2015 general election that brought the APC government to power, for example, the party won both the presidency and the highest number of seats in the parliament (Ojibara, 2017; Okpe \& Taya, 2018). On this ground, therefore, the Nigerians believed that the two institutions would interact better to facilitate public policies, consolidate democracy and good governance. Sadly, immediately after the new administration was inaugurated, the style of interaction between the executive, the legislature and the ruling party became enmeshed with crisis over the choice of leadership in the legislature (Ojibara, 2017). In fact, since the return of the fourth republic in 1999, the pattern of interaction between the organs remains more crisisdriven (Chima et al., 2018; Egwu et al., 2020; Igbokwe-Ibeto \& Anazodo, 2015). The above views confirmed what has been the pattern of interaction between the institutions and were often influenced by 
personal interests rather than public interest. Several studies have also been carried out in this regard and these include the works of Fashagba (2019), Baba (2019), Okpe and Taya (2018), but none concentrated on the crisis between the institutions under the APC- led government between 2015 and 2019. This study, therefore, filled the gap in the literature as the objective centered on unraveling the factors that led to the crisis between the institutions and its impact on good governance in Nigeria.

\section{LITERATURE REVIEW}

\section{Legislature-Executive Relations}

Considering the concepts of the legislature and the executive and their importance in a democratic government, Fashagba (2019) described the legislature as a key state political institution. It is an important constitutional unit that links the state and the people together through a legal structure known as the constitution (Muheeb, 2019). As Muheeb (2019) added, the parliament represents the symbol of popular representation and the most organized avenue for political actions and mobilization of public consents, while the executive, Heywood (2007) noted, is an irreducible arm of the government. In some democracies, Laski (1992) observed, it exists, first, to draft and take decisions on public bills for parliamentary endorsement, and second, to safeguard all public services, government MDAs and ensure their maximum operation as defined by the parliament. According to Baba (2019), these institutions (the legislature and the executive) are critical in steering the state administration for good governance in a democracy. While the executive, he added, constitutionally makes public policies and execution, the legislature enacts laws and controls government activities. The control is often achieved through oversight for the essence of transparency and accountability, and to reduce public waste.

In addition to the above, Baba (2019) added, relations between institutions like the legislature and the executive are often dissected within a presidential democracy like Nigeria. This is because in military, monarchy or parliamentary administrations, the institutions, their powers, and functions are often fused. Therefore, in a presidential system, the institutions' relations usually involve the interaction that happens between them (Bassey, 2002, as cited in Okpe \& Othman, 2020). This interaction, as revealed by Kopecký (2004), remains one of the important defining characteristics of any working democratic government. Also, the degree of constitutional powers entrusted to them is key to their interaction as they define their legal framework of relations (Lijphart, 2004). Considering the importance of the institutions, they represent the key to good governance in Nigeria. According to Holme (2007), Aiyede and Isumonah (2002), good communication between the institutions remains paramount as it would promote good governance, constitutional practice, and the rule of law. The above points to the importance of effective engagements between the institutions and are only achievable when they are active, functional 
and interface in a pattern that consolidates citizens' confidence in the government.

In Nigeria, their powers and functions are defined in the 1999 Constitution due to their importance to the political system. However, Oni (2014) revealed, notwithstanding that Nigeria jettisoned the Westminster model it adopted in 1963, and the embracement of a presidential democratic governance in 1999, neither of the two succeeded in guaranteeing a stable political system needed for development and good governance in the country. Also, the pattern of interaction between the institutions has remained the most problematic (Okon et al., 2013; Oni, 2014). Since the emergence of the fourth republic (Momodu \& Matudi, 2013), their pattern of relationship remains more of crisis and disagreements with more negative consequences on policy formulation, implementation, and good governance. What is more disturbing, they concluded, is that after several years of democratization, the politicians have refused to adjust from their tradition of impunity, deliberate disregard, and abuse of the rule of law introduced into the Nigerian politics by the military. The above showed that the institutions have not been more responsive to their roles and to the citizens due to their crisis pattern of interactions.

\section{Legislature-Executive Crisis}

To understand the concept of legislatureexecutive crisis, it is pertinent to explore the word "conflict". The word 'conflict' or crises emanates from a Latin concept known as "configure", and simply implies to strike together (Albert, 2001; Barash \& Webel, 2013). For instance, Momodu and Matudi (2013) observed that from time immemorial, the term remained as omnipresent and indispensable when it comes to social interaction in human societies. According to Wolff (2006), it refers to an occasion where two or more people, groups or institutions like the legislature and the executive, struggle for incompatible goals or interest. He concluded that crisis emerges in most cases due to struggle and interest over material gains or power and often between individuals or public leaders. Because of their vested interest, they often chose crisis over negotiation, and preferred violence over cooperation. Building on the above, Bassey (2002, as cited in Okpe \& Othman, 2020) explained the executivelegislature crisis as a situation where the executive opposes the interest or actions of the legislature or vice versa. He added that it involves a state of absolute or partial incompatibility where either institution is in persistent affray with the other. He concluded that it often involves issues relating to public policy, their perception and pattern of understanding.

According to Momodu and Matudi (2013), a legislature-executive crisis connotes a situation in which both institutions strive for incompatible goals and interests. One arm sees the other as an enemy or makes efforts to block or frustrate its interests. In Nigeria, for instance, the pattern of interaction between the two institutions remains crisis- driven and problematic (Okon et al., 2013; Oni, 
2014). Their crises often emerge during the public budget presentation, endorsement, implementation, and evaluation processes (Godswealth et al., 2016; Lewis, 2011). According to Okon et al. (2013), relations between government institutions often take diverse patterns of interactions and these involve crisis, negotiation, compromise, and coalition. For example, Okon et al. (2013) further revealed that under the Nigerian 1999 Constitution, the legislature enjoys the legal power to make laws, while the executive implements such laws for good governance. However, as revealed by Oni (2014), and Momodu and Matudi (2013), since the emergence of the fourth republic in 1999, amongst the key factors threatening Nigeria's democracy and good governance is the crisis pattern of interaction between the legislature and the executive. It has affected political stability and good governance. In fact, it is even against the principle of institutional relations for quality service delivery.

\section{Legislature-Executive Crisis in the APC- led Government in Nigeria}

From the legions of literature, cases of crisis between the legislature and the executive especially between 2015 and 2019 have emerged. Most of the crisis, as revealed by Ojibara (2017) and Okpe and Taya (2018), ranged from several factors which included executive interference in parliamentary leadership amongst other public policy issues. According to Ojibara (2017) a new political party (APC) which historically came into being through political alliance in 2013, defeated the governing Peoples
Democratic Party (PDP) in the 2015 general election. PDP was in power from 1999 until 2015 before it lost to APC. APC won the presidency and the majority seats in the parliament (Okpe \& Taya, 2018). It was a new turnaround in the Nigerian political system.

With the above development, Nigerians believed that the two institutions would relate better. However, the case became different as after the inauguration of the new government in May 29, 2015, a crack in the new government became obvious. Crisis over who becomes the principal leaders of the parliament planted the first seed of discord between the executive, the ruling party, and the legislature (Ojibara, 2017; Okpe \& Taya, 2018). The emergence of Senator Bukola Saraki as the President of the Senate and Yakubu Dogara as the House of Representatives' Speaker against the desire of the executive, led to a huge crisis between the institutions (Baba, 2019; Fashagba, 2019). Consequently, the unresolved disagreement which started in 2015, as Baba concluded, remained alive, so much so that in 2018 the President of the Senate and the House of Representatives' Speaker, went back to PDP, their former party. It was all crisis between the institutions throughout the period.

In addition to the above, the findings of Okpe and Taya (2018) which revealed the crisis between the institutions over the 2016 national budget, corroborated the result of Ojibara (2017). According to the authors, first, the crises were about inconsistencies in what the chief executive presented to 
the parliament as the 2016 budget, and what the MDAs presented. Second, the suspected disappearance of the budget in the parliament after it was presented, and third, the likelihood that the executive laid varying budgets to the parliament. These crises over the 2016 budget, they concluded, reflected the absence of cordial relations between the organs as they affected the timely implementation of the budget. Similarly, Taiwo (2014) revealed that the executive and its agencies often refused to obey the parliamentary summons. He added that the lawmakers, on many occasions, summoned the heads of the executive MDAs, but they ignored such summons. For example, he concluded that in 2016, the Nigerian Senate summoned the Comptroller-General of the Nigerian Custom, the Secretary to the Federal Government (SGF), and the Inspector- General of the Nigerian Police (IGP), but they all ignored the summon. It led to a serious show of power before they later obeyed the summon (Ajakaye, 2018; Ogundipe, 2017). The entire actions of the executive MDAs violated the 1999 Constitution and the power of the legislature to query its activities.

Other crises, as revealed by literature, between the institutions were the legislature's rejection to confirm the executive nominee. On this case, Okpe and Taya (2018) explained that immediately the crises over the national budget, the constituency projects and the welfare programs between the institutions appeared to be over, a crisis on the issues of the executive appointment of nominees and the confirmation by the parliament emerged. The executive nominated the head of the Economic and Financial Crimes Commission (EFCC) but the parliament rejected the confirmation. The above incident was also confirmed by Baba (2019), Fashagba (2019) and Okakwu (2018). They all agreed that notwithstanding that the confirmation of the EFFC Chairman was rejected by the legislature, the executive allowed the Chairman to remain in office throughout the tenure. It was a clear violation of the constitution and institutional authority. There was also another bone of contention on the Electoral Act amendment before the 2019 general election. Results showed that the parliament amended the Act severally before the 2019 elections and sent it for executive endorsement on three occasions, but the executive withdrew its endorsement (Peter \& Peterside, 2019). According to DailyTrust ("Bills Buhari has refused", 2019), the action of the executive set the organs against one another due to their disagreement on the matter.

Accordingly, Muktar (2018) explained that when the 2019 general election came nearer, the political system became enmeshed with political intrigues which emanated from the crisis pattern of relations between the organs. On this note, Baba (2019) made it known that the unresolved leadership crisis in the legislature between the two institutions which started in 2015, became large that by 2018 both the Senate President and the House of Representatives' Speaker defected to PDP, the opposition party. He concluded that the change of party by the two leading leaders of the parliament 
never went down well with the executive. Therefore, the executive plotted to impeach the principal leaders. As such, the executive besieged the National Assembly through its State Security Services (SSS). It was a disturbing issue because such a move by the executive was unwarranted. Based on the 1999 Constitution, the legislature is an independent institution with its own powers and functions for the benefit of good governance. Therefore, the role of the executive was an aberration on the legislature and a violation of the constitution and separation of their powers.

\section{Democratic Governance and Good Governance in Nigeria}

Under Nigeria's fourth republic in 1999, its presidential democracy and good governance continued to gather momentum amongst scholars. According to Isma'ila and Othman (2016), while democracy and governance remain interrelated, they are equally independently distinct and exceptional. They qualified democracy as a government and constitutional system where the citizens select or elect their representatives to carry out responsibilities involving the allocation of resources, values, and public welfare. The World Bank (2005, as cited in Isma'ila, 2016) noted that governance reflects a system where the constitutional powers of the state are used to manage her political and economic resources for development. It involves a process in which public powers are granted and used for the service of the people (Imobighe, 2013; Isma'ila \& Othman,
2016). Democratic governance, therefore, as noted by Isma'ila (2016), reveals a process in which state institutions like the legislature and the executive operate in accordance with democratic processes. As they added, it encompasses exercising the teachings of democracy. Good governance, according to Elaigwu (2014), encompasses how citizens and leaders that enjoy the state authority make use of such processes to realize the needs of the people. It simply involves the delivery of welfare services to the people, preservation of law and the pursuit of peoples' interests.

According to Isma'ila (2016), democratic governance and good governance involve the exercise of democratic ethos that have to do with popular sovereignty and majority rule. This also includes public empowerment, rule of law, functional constitution, periodic credible elections, respect for human rights and freedom of speech. In the Nigerian context, he argued, the above democratic ethos is neither strong nor active enough to effect positive changes in the system. The absence of active operations in line with democratic principles by the state institutions like the legislature and the executive characterized the system. He believed that it is one thing to have democracy, but a different thing to have a democratic working- system. Therefore, the absence of a working democracy in a democratic system is tantamount to a failure of democratic governance. According to Ogbo and Avidime (2016), the return to democratic governance in 1999 was a welcome development amongst the 
Nigerians, but the experiences remained problematic for the country. Positive achievements like uninterrupted democratic transitions, economic dividends, improved political and civil rights were witnessed, but the level of success connected to the democratic experiences appeared to be outshone by poor governance. The problems of industrialization, poverty, unemployment, decline of infrastructure, insecurity over lives and property, political corruption and weak public institutions remained obvious in the system. Consequently, the degree of citizens' trust in the democratic system, the institutions and their actors continued to decline.

Also, challenges of ethnic cleavages, electoral malpractices, insecurity and religious crisis continued to impact negatively on Nigeria's democracy and the fourth republic (Ogbonnaya et al., 2012). They added that institutions like political parties, the lawmaking organs and their oversight roles over the executive, and instruments of checks and balances could be seen, but inadequacy and weakness of these institutions remained the greatest obstacle to the delivery of goods and services. They concluded that the institutions had failed to secure public lives and property, ensure credible electoral processes, sanction corrupt public officers for their wrong activities, as well as the perpetrators of violence. All these indices contradicted the ethics of democratic governance. The above indices, Oni (2014) argued, were products of the persistent crisis between the legislature and the executive. To him, the Nigerian presidential democratic governance under the fourth republic had failed to guarantee a stable political system and the persistent crisis between the legislature and the executive remained the most problematic. He concluded that the institutions interacted under mutual suspicion, animosity and political enmity largely orchestrated by political godfathers working with the executive. According to Momodu and Matudi (2013) the institutions dysfunctional crisis relations often deadlocked the processes of publicpolicy formulation and implementation, and thereby, ultimately negatively impacted good governance. The indices could not guarantee public interest, good governance, and democratic consolidation in Nigeria.

\section{MATERIALS AND METHODS}

This study was anchored in understanding the factors responsible for the legislatureexecutive crisis under the APC-1ed government in Nigeria between 2015 and 2019, and its implication on good governance. To realize the above, the study relied mainly on the descriptive qualitative research method. According to Creswell (2014), a research method has to do with the body of choices and processes a researcher engages to study and unveil a phenomenon of interest. The reason and validation behind the adoption of the method to understand the causative factors that led to the institutions' crisis in Nigeria, were because the legislature and the executive are social and democratic institutions. Also, the public often have opinions on how they relate, interact, and perform their 
constitutional roles. As noted by Wright and McKeever (2000) qualitative research stands as a perfect research instrument in carrying out an investigation about a social phenomenon that involves hearing or gathering public opinion. Magilvy (2003) explained that the intention behind this research method is often entrusted to the researcher's effort to cast a deep thought and articulate proper descriptions of his subject of interest. Materially, only secondary data were used such as academic resources that share knowledge on institutional relations, political parties, good governance, and democracy. The materials included reports from the parliament, the executive, civil society organizations, political parties, and books. Books written by Omotoso and Oladeji (2019), Fashagba et al. (2019), Baba (2019), Fagbadebo and Ruffin (2019) were amongst others. Lastly, it also used the institutional theory of conflict (crisis) to support the secondary data for clarity, develop linkages and to arrive at acceptable conclusions.

\section{Theoretical Framework}

This study adopted the institutional theory of conflict to explain the causative factors that led to the legislature-executive crisis under the APC- led government between 2015 and 2019, and its implication on good governance. This theory, Garuba and Salawu (2020), and Osakede et al. (2017) observed, was developed by Schmidt (2006). According to Osakede et al. (2017), the theory creates room for an in-depth examination of the crisis between government institutions. In fact, Garuba and Salawu (2020) further represented the theory as the best guide in assessing how crisis between the legislature and the executive under the APC government resulted in major political rivalries and as such, led to the poor formulation and implementation of public policies which gave room to bad governance in the country. The theory placed emphasis on the interactions between institutions, implementation of values, resources, and the way in which the pursuit of interests often led to crisis (Osakede et al., 2017). It believes that crisis emerges due to the incompatibility of goals, beliefs, objectives, roles, and interests between the state organs.

More importantly, crisis, as noted by Albert (2001), simply means to strike together. It is omnipresent (Momodu \& Matudi, 2013) and remains indispensable in social communication (Barash \& Webel, 2013; Osakede et al., 2017). It connotes disagreement, opposition, contest, or controversy amongst actors with opposing ideas, needs or beliefs (Andre, 1994; Fatile $\&$ Adejuwon, 2016). The theory views the state as a political platform of interest within which important actors like the legislature and the executive struggle over limited resources (Garuba \& Salawu, 2020). In this context, Osakede et al. (2017) further observed that the two institutions often pursue an incompatible objective which makes crisis inevitable, especially when performing their constitutional roles.

According to Sears (2008), a legislatureexecutive crisis happens when the state's powers and resources are unevenly distributed 
between the arms. It also manifests due to the incompatibility of roles and interference by one institution on another. According to Momodu and Matudi (2013), occasional crises between the institutions is predictable and unavoidable, but if well managed, can be healthy for the progress of democracy and good governance. In Nigeria however, the crisis between the institutions is seen as the most problematic to democracy and good governance (Oni, 2014; Osakede et al., 2017). In fact, the institutions have refused to learn and change from their impunity (Momodu \& Matudi, 2013). For instance, Okpeh (2014) argued that in the US, such crisis is perceived as necessary for the consolidation of democratic experience but is entirely different in Nigeria as results from policy formulation and implementation remain largely elusive. This infers that their constant crisis remains a bane for good governance. As noted by Egobueze et al. (2020), the Nigerian political class intentionally made the institutions to be weak to exercise control over public resources. Based on this, therefore, the application of the theory to explain the causative factors that incited crisis between the legislature and the executive under the APC government in 2015-2019 cannot be overemphasized. It enables the crisis causative factors to be well understood.

\section{RESULTS AND DISCUSSION}

From the body of literature reviewed, several factors responsible for the crisis between the legislature and the executive under the APC -led government in 20152019 emerged. These factors included leadership interference and legislative oversight amongst others. They are analyzed and explained below.

\section{Leadership Interference}

This factor, as revealed by literature, often emanated from the executive and was responsible for almost all the crises between the institutions under the APC- led government. On this matter, Baba (2019) and Oni (2013) made it clear that while the Nigerian 1999 Constitution in Section (47) and Section (4) recognized the legal powers and roles of the National Assembly, Section (130) and Section (5) of the same constitution also established the functions and powers of the executive. However, as they both further revealed, the exercise of these constitutional provisions led to several crises between the institutions and often emanated from executive interference and intention to dominate parliamentary leadership and businesses. For instance, Baba (2019) observed that executive interference in the leadership of the National Assembly continued in 2015 after the general election and the inauguration of the new government. He observed that despite the expectation that the alternation in power which resulted in the defeat of PDP and the emergence of the APC government and that the legislature and the executive would improve their relations, the institutions' acrimony remained a major challenge in the system. The emergence of the APC government and the defeat of PDP refused to change the power tussle that often characterizes the decision of who becomes the principal leaders of the parliament. 
According to Ojibara (2017) after the inauguration of the new government in 2015, the next procedure was to elect lawmakers who would serve as the principal leaders of the parliament. In that election, he added, the executive and the ruling party anointed Senator Ahmad Lawal and Honorable Femi Gbajabiamila as their favorite candidates for Senate President and Speaker of the House of Representatives. The two houses perceived the executive and the ruling party as interfering in the legislature's constitutional right to freely elect their principal leaders. The lawmakers did not only turn down the two candidates proposed by the executive and the ruling party, but they also went ahead and elected Senator Saraki as the Senate President and Honorable Dogara as their Speaker (Baba, 2019). According to Baba (2019), the emergence of Senator Bukola Saraki as the Senate President and Honorable Dogara as the Speaker of the House of Representatives immediately after the general election in 2015 against the executive's choice, crippled their high chances for better interaction and teamwork. The unresolved leadership crisis which started in 2015 between the institutions, grew so wide that the President of the Senate as well as the House of Representatives' Speaker, returned to their original party, PDP (Fashagba, 2019). This was responsible for various crises and instabilities in the parliament and throughout the administration. Executive interference and crisis between the institutions were often based on personal interest. This also confirmed the submission of the institutional theory of conflict and was against democratic consolidation. The parliamentarians, ordinarily, have the legal rights to elect their leaders without external interference.

\section{Legislative Oversight}

Notwithstanding executive interference on the constitutional independence of the legislature, an oversight function of the legislature over the executive was another factor that led to conflict between the two organs. As noted by Pelizzo and Stapenhurst (2013) this legislature's oversight function encompassed constitutional roles built around the formulation and assessment of public policies. It was centered on public expenditure, assent to public bills such as the national budget, approval of executive nominees, summoning of its MDAs and seeking explanation on the execution of several activities within their disposal. Regarding the above, it is important to note that the exercise of these constitutional duties by the parliament led to several crises between the institutions.

The crises were obvious in the 2016 national budget, the illegal withdrawal of $\$ 1$ billion by the executive from the public treasury against parliamentary sanction, parliament's refusal to confirm the executive nominee (the EFCC Chairman) and his persistent stay in the office against the provision of the constitution. Others were crises over the refusal to obey parliamentary summons by Hameed Ali, (the Nigerian Custom Director-General) and Ibrahim Kpoti (Inspector-General of Police) amongst 
others (Ojibara, 2017; Okpe \& Taya, 2018). According to Baba (2019), these crises dented their spirit of partnership. In fact, as he concluded, the strained pattern of interaction between the arms prolonged the 2016 budget and its timely implementation. The crises were not healthy for good governance as they often had their roots in crises of personal interest rather than public interest. They affirmed the submission of the institutional conflict theory, and could not build democracy.

\section{Lack of Capacity Building and Poor Experience}

This simply involves the ability of the lawmakers and the executive organ to carry out their constitutional powers and roles with knowledge and expertise. However, Eme and Asadu (2017) observed that inadequate competence affected good interaction between the institutions in Nigeria. Many of the public office- holders, they added, instead of using funds budgeted for their capacity development through further training to enhance their working knowledge, often diverted such funds for their personal use. Consequently, as they concluded, they ended up neither having the required knowledge in their field or the technical know-how to improve their relations. Also, results emerged that to castigate some of the legislators who were seen to be stubborn towards the executive, the executive often ensured that such lawmakers lost their seats in the next election (Jombo, 2019). He concluded that this move by the executive against such lawmakers negatively affected the degree of vital parliamentary experience which was supposed to aid their capacity in relating with the executive. This incident is not rare in Nigerian politics and it explains why some of the lawmakers' defect to different parties that can serve their interests especially when elections are approaching. They all involve crisis of goals and interest.

\section{Personal Interest and Corruption}

Politics of corruption and personal interest cannot be overruled in any political setting. In Nigeria, for instance, results emerged that constant drive by politicians and other public office- holders like the legislature and the executive to personalize public office, is often a common factor in examining crises between the institutions (Oni, 2013). According to Fagbadebo (2016) the general perception of Nigerians with regards to politicians is that they usually go into public office not basically for the public interest. Along the same line, Eme and Asadu (2017) noted two types of corruption that often caused crises between the institutions. One type involved legislature- and executiveinduced corruptions which often led to crises of confidence and trust between the institutions. For instance, they concluded that Obasanjo's alleged bribery to some parliamentarians in 2003 to impeach their Speaker, was an executive-induced corruption which led to a crisis between the institutions. Conversely, the bribery allegation against the President of the Senate, who served in 2003-2005, was a legislatureinduced corruption. Furthermore, Nwagwu 
(2014) observed that some parliamentarians often see their oversight responsibility as a quick way to become wealthy. They engage in all degrees of tactics and influence to join a committee in the legislature, which is often engineered for personal interest. They extort, intimidate, and humiliate their prey (executive MDAs) and force them to carry out their interests (Omotoso \& Oladeji, 2019). Their attitudes contradict democracy, rule of law and good governance as everything appears on personal pursuit.

\section{Communication Gap and Poor Lobby}

These issues were among the factors responsible for the institution crisis under the APC- led government. Eme and Asadu (2017) revealed that beyond their interface and interaction- session during their national budget presentation and defense by the executive MDAs, they hardly exploited other avenues for joint interaction. They hardly consulted each other to deliberate on their relations and public policies. Under the APC government, results showed that the parliament often accused the executive of not lobbying the institution for quick passage of bills, the national budget, anti-corruption war and confirmation of nominees (Ojibara, 2017). However, as Ojibara concluded, lobbying amongst Nigerian parliamentarians is often about the distribution of patronages and brown envelopes. The parliamentarians often want President Buhari to maintain the culture of sharing money and patronages in return for their support. It is all about selfish interest and not about the public. It could explain the reason for their constant crisis.

\section{Implication of Legislature-Executive Conflict to Good Governance in Nigeria}

Generally, as noted by Okpe and Othman (2020), the pattern of interaction between two state institutions, by implication, can either produce negative or positive impacts to democracy and good governance. On this, Eme and Asadu (2017) asserted that the crisis between the organs could not only represent an important instrument in controlling government excesses but could also serve as a gridlock over important public policies. They concluded that it could affect good governance and render the early delivery of democratic dividends futile. According to Muheeb (2019) the parliament between 1999 and 2015, before the emergence of the APC government, passed a total of 248 bills into law, but from June 9, 2015 to July 2018, it passed 213 bills into law (Oni et al., 2019; Umoru, 2018). This was notwithstanding the crisis between the two institutions. As further revealed by Muheeb (2019) aside these achievements, politics of personal interest had a serious negative impact on the much-anticipated active relationship between the institutions for good governance. The chaotic pattern of interaction (Baba, 2019) succeeded in disrupting the achievement of the key democratic values of accountability, probity, transparency, and equitable management of public resources. Public policy issues such as lawmaking and parliamentary oversight in the said period were hardly agreed upon. Budget proposals, as he concluded, were unreasonably delayed and non-implementation of budgets was barely 
sanctioned by the parliament, which affected good governance. According to Fashagba (2019), the change to a good life that the APC administration pledged to the Nigerians was lost in the crisis between the institutions. Consequently, it led to poverty, hardship, and economic deprivation in the country. The whole conflict was against the interest of the people as it brought more negative consequences with less benefit to the masses. They were all driven by crises of personal interest against the public interest.

\section{CONCLUSION}

In most institutional relations such as in a presidential democracy like Nigeria, a crisis is inevitable between the executive and the legislature. However, a healthy interaction for public interest and good governance cannot be overemphasized. According to Okpe and Othman (2020), these institutions perform important duties in aiding an active political system, providing better goods and services through good governance, as well as consolidating democracy. With respect to the above, this study aimed to unravel the factors that led to the legislature-executive crisis in Nigeria's fourth republic democratic governance, especially under the APC- led government in 2015-2019. To achieve the above aim, the study relied mainly on the descriptive qualitative research approach as well as secondary data. From the analysis, factors responsible for the crisis emerged and this included executive interference in parliamentary leadership. Other factors were the legislature's oversight, lack of capacity building and experience, personal interest, corruption, communication gap and poor lobby, and inability to resolve their interest within their party.

By implication, the results also showed that in 1999-2015, the parliament was able to pass 248 bills into law (Muheeb, 2019), but in 2015-2019, it passed 213 bills. It showed a greater performance (Oni et al., 2019; Umoru, 2018). However, Muheeb (2019) added that aside the above achievements, politics of personality which emanated from the crisis impacted more negatively on the political system. It disrupted accountability, transparency, and fair management of public resources. Budget proposals were unfairly delayed, poor implementation of policies, lawmaking and inadequate oversight led to poverty and poor governance. According to Fashagba (2019) all positive changes the APC government pledged to the Nigerians were lost in the crisis. The above are similar to the findings of Okpe and Othman (2020), Ojibara (2017), Okpe and Taya (2018), and Egwu (2020). All these were against the interest of the public and the political system. Therefore, there is need for synergy between the institutions for the purpose of public interest. They must obey their institutional independence and promote collaboration for public interest. They must respect the constitution, its provisions, and the rule of law to ensure democratic consolidation. Finally, the study would be of benefit to the institutions, researchers, and the people. Further studies can examine the legislature-judiciary pattern of relations under the fourth republic in Nigeria. 


\section{ACKNOWLEDGEMENT}

The main author of this study wholly acknowledge the support offered by the School of International Studies (SOIS), Universiti Utara Malaysia (UUM); most importantly, the co-author, Professor Muhammad Fuad Othman as Ph.D. supervisor, and Dr. Nazariah, B. Osman, the Dean of the School of International Studies, UUM.

\section{REFERENCES}

Aiyede, R., \& Isumonah, V. A. (2002). Towards democratic consolidation in Nigeria: Executivelegislative relations and the budgetary process. Development Policy Centre.

Ajakaye, R. (2018, May 10). Nigeria: Police hit back over chief refusing summons. Africa. https:// www.aa.com.tr/en/africa/nigeria-police-hitback-over-chief-refusing-summons/1141307

Albert, I. O. (2001). Introduction to third party interview in community conflicts peaceful transformation forum. John Arches publication.

Andre, M. F. (1994). Methodological problems in comparative politics. Journals of Theoretical Politics, 6(3), 12-56.

Baba, Y. T. (2019). Executive-legislature relations: Evidence from Nigeria's Fourth Republic. In J. Y. Fashagba, O. M. Ajayi, \& C. Nwankwo (Eds.), The Nigerian National Assembly (pp. 143-164). Springer, Cham. https://doi.org/10.1007/978-3030-11905-8_9

Barash, B., \& Webel, C. (2013). Peace and conflict studies. Sage Publications Inc.

Bills Buhari has refused to sign, and why. (2019, April 6). Daily Trust, 1.

Chima, E., Bello, M. B., Okoroafor, F. O., \& Obilor, O. I. (2018). Conflict management in intergovernmental relations in Nigeria: Issues and prospects. GNOSI: An Interdisciplinary Journal of Human Theory and Praxis, 1(1), 17-24.

Creswell, J. W. (2014). Research design: Qualitative, quantitative, and mixed methods approach. Sage.

Egbefo, D. O. (2015). Accountability and good governance at the grassroots level in Nigeria: Option for rural poverty alleviation. Journal of Research in National Development, 13(1), 10-20.

Egobueze, A., Ogele, E. P., \& Ajunwo, D. (2020). Legislative conflicts and democratic consolidation in Nigeria's Fourth Republic: An interrogation of the National Assembly. American Research Journal of Humanities and Social Sciences, 6(1), 1-16.

Egwu, E. M. (2020). Managing legislature-executive relationship and conflict in the Nigerian presidential democracy. International Journal of Asian Social Science, 10(7), 339-349. https:// doi.org/10.18488/journal.1.2020.107.339.349

Egwu, E. M., Alabi, J. O., \& Sule, J. G. (2020). An exploration of legislative-executive conflicts from the perspective of human relations in Nigeria. International Journal of Social and Administrative Sciences, 5(1), 16-29. https://doi. org/10.18488/journal.136.2020.51.16.29

Elaigwu, J. I. (2014). Democracy and democratic deficits. In J. I. Elaigwu (Ed.), Federalism and democracy in Nigeria: Fifty years after (pp. 242-256). Institute of Governance and Social Research (IGSR).

Eme, O. I., \& Asadu, I. (2017). Exploring the factors responsible for executive-legislative conflict in Nigeria. Journal of Security Studies and Global Politics, 2(1), 49-59.

Fagbadebo, O. M. (2016). Exploring the politics of impeachment in Nigeria's Presidential System: Insights from selected states in the Fourth Republic, 1999-2007 [Unpublished doctoral dissertation], University of KwaZulu-Natal. 
Fagbadebo, O., \& Ruffin, F. (Eds.). (2019). Perspectives on the Legislature and the Prospects of Accountability in Nigeria and South Africa. Springer, Cham. https://doi.org/10.1007/978-3319-93509-6

Fashagba, J. Y. (2019). Exploring the Nigerian central legislative institution. In J. Fashagba, O. R. Ajayi, \& C. Nwankwor (Eds.), The Nigerian National Assembly (pp. 1-13). Springer, Cham. https://doi.org/10.1007/978-3-030-11905-8_1

Fashagba, J. Y., Ajayi, O. R. M., \& Nwankwor, C. (Eds.). (2019). The Nigerian National Assembly. Springer, Cham. https://doi.org/10.1007/978-3030-11905-8

Fatile, J. O., \& Adejuwon, K. O. (2016). Legislativeexecutive conflicts and democratic governance in Nigeria's fourth republic. International Journal of Innovation Research in Social Science and Management Techniques, 3(1), 91-110.

Garuba, R. O., \& Salawu, I. O. (2020). Adversarial executive-legislative relations on governance in Nigeria: Insights from Buhari's presidency (2015-2019). KIU Journal of Humanities, 5(2), 137-144.

Godswealth, I. C., Ahmad, Z. B., \& Jawan, J. (2016). Factors influencing the executive and legislative conflict in Nigeria political development. IOSR Journal of Humanities and Social Science, 21(8), 20-25.

Heywood, A. (2007). Politics (3rd ed.). Palgrave Macmillan's.

Holme, R. (2007). Relations between the executive, the judiciary and parliament. The Stationery Office Limited.

Igbokwe-Ibeto, C. J., \& Anazodo, R. O. (2015). Managing executive-legislature relationship for good governance and service delivery in Nigeria. Review of Public Administration and Management, 4(8),13-24.
Imobighe, T. A. (2013). Governance and Nigeria's national security. In T. A. Imobighe \& S. I. Ebohon (Eds.), Themes and issues in Nigerian governance and politics (pp. 265-292). National Institute for Policy and Strategic Studies (NIPSS).

Isma'ila, Y. (2016). Malpractices in Nigeria's Fourth Republic elections: Challenges of democratic governance [Doctoral dissertation, Universiti Utara Malaysia]. http://etd.uum.edu.my/6418/2/ s95431_02.pdf

Isma'ila, Y., \& Othman, Z. (2016). Globalization and democratization in Nigeria's quest for democratic governance in the Fourth Republic. Mediterranean Journal of Social Sciences, 7(1), 386-386. http://doi.org/10.5901/ mjss.2016.v7n1p386

Jombo, O. C. (2019). Examining the peculiarities of executive-legislative relations in Nigeria's presidential system: Insights from selected states in the Fourth Republic, 1999-2015. [Doctoral dissertation, University of KwazuluNatal]. https://ukzn-dspace.ukzn.ac.za/ handle/10413/16503

Kopecký, P. (2004). Power to the executive! the changing executive-legislative relations in eastern Europe. The Journal of Legislative Studies, 10(2/3), 142-153. https://doi. org/10.1080/1357233042000322274

Laski, H. J. (1992). A grammar of politics. George Allen and Unwin.

Lewis, P. M. (2011). Nigeria country report. University of Cape Town Centre for Social Science Report.

Lijphart, A. (2004). Constitutional design for divided societies. Journal of Democracy, 15(2), 96-109. https://doi.org/10.1353/jod.2004.0029

Magilvy, J. K. (2003). Qualitative designs. In K. S. Oman, M. Krugman, \& R. Fink (Eds.), Nursing 
research secrets (pp. 123-128). Hanley \& Belfus, Inc.

Momodu, A. J. (2012). Legislature and good governance in Nigeria's democratic system: Implications on delivering dividends of democracy. Journal of Pedagogical Thought, 8180(8), 39-56.

Momodu, A. J., \& Matudi, G. I. (2013). The implications of executive-legislative conflicts on good governance in Nigeria. Public Policy and Administration Research, 3(8), 30-42.

Muheeb, I. O. (2019). The trajectory of the legislature, lawmaking, and legislation in Nigeria. In J. Fashagba, O. R. Ajayi \& C. Nwankwo, (Eds.), The Nigerian National Assembly (pp. 33-56). Springer, Cham. https://doi.org/10.1007/978-3030-11905-8_3

Muktar, U. M. (2018, August 31). APC's defection: A chance to seize opportunity from crisis. The News. https://www.Thenewsnigeria.Com. Ng/2018/08/31/Apcs-Defections-A-Chance-ToSeize-Opportunity-From-Crisis/

Nwagwu, E. J. (2014). Legislative oversight in Nigeria: A watchdog or a hunting dog? Journal of Law, Policy \& Globalization, (22), 16-24.

Ogbo, U. S., \& Avidime, S. S. (2016). Assessing democratic governance in the Nigerian Fourth Republic, 1999-2014. European Scientific Journal, 12(29), 142-155. https://doi. org/10.19044/esj.2016.v12n29p142

Ogbonnaya, U. M., Omoju, O. E., \& Udefuna, N. P. (2012). The challenges of democratic governance in Nigeria's Fourth Republic. Mediterranean Journal of Social Sciences, 3(11), 685-693.

Ogundipe, S. (2017). Why I will not appear before Nigerian Senate, Hameed Ali. Premium Times. https://www.premiumtimesng.com/news/ headlines/226777-i-will-not-appear-nigeriansenate-hameed-ali.html
Ojibara, I. I. (2017). A governing party in disarray: Executive-legislative relations under APC government. Global Journal of Human-Social Science, 17(1), 40-50.

Okakwu, E. (2018). Senate right to reject Magu as EFCC chairman, Court rules. Premium Times. https://www.premiumtimesng.com/ news/headlines/257349-updated-senate-right-toreject-magu-as-efcc-chairman-court-rules.html

Okon, B. A., Abia, R. P., Ekok, O. C., \& Antigha, B. U. (2013). An examination of causes and consequences of conflict between legislature and executive in Cross River State, Nigeria. Academic Journal of Interdisciplinary Studies, 2(1), 179-187. http://doi.org/10.5901/ajis.2013. v2n1p179

Okpe, V. V., \& Othman, M. F. (2020). Assessment of legislature-executive pattern of relations in Nigeria's democratic governance of the Fourth Republic: Prospects and challenges. Pertanika Journal of Social Science \& Humanities, 28(4), 2844-2860. https://doi.org/10.47836/ pjssh.28.4.19

Okpe, V. V., \& Taya, S. (2018). Institutional perspective: Legislative-executive relations under Nigeria's democratic dispensation. International Journal of Research, 5(22), 828851.

Okpeh, O. (2014): Foreword to history of executivelegislature relation in Nigeria, 1914-2007. University of Ibadan Press.

Omotoso, F., \& Oladeji, O. (2019). Legislative oversight in the Nigerian Fourth Republic. In J. Y. Fashagba, O. R. Ajayi, \& C. Nwankwo, (Eds.), The Nigerian National Assembly (pp. 57-72). Springer, Cham. https://doi.org/10.1007/978-3030-11905-8 4

Oni, S. (2014). Governance and legislatureexecutive relations at the state government level of Nigeria's presidential system. Politické vedy, 17(4), 142-156. 
Oni, S., Olanrewaju, F., \& Deinde-Adedeji, O. (2019). The legislature and law making in Nigeria: Interrogating the National Assembly (1999-2018). In J. Fashagba, O. R. Ajayi \& C. Nwankwor (Eds.), The Nigerian National Assembly (pp. 15-31). Springer, Cham. https:// doi.org/10.1007/978-3-030-11905-8_2

Oni, S. O. (2013). Legislature-executive relations in the presidential system: A study of Lagos and Ogun States, Nigeria, 1999-2011 [Doctoral dissertation, Covenant University]. http://eprints. covenantuniversity.edu.ng/1462/

Osakede, K. O., Ijimakinwa, S. O., Adesanya, T. O., \& Oshineye, A. A. (2017). Executivelegislative face-off in Nigerian democracy and its implication on good governance. Review of Public Administration and Management, 6(12), 60-68.

Pelizzo, R., \& Stapenhurst, R. (2013). Parliamentary oversight tools: A comparative analysis. Routledge.

Peter, A. M., \& Peterside, Z. B. (2019). The roadmap to the 2019 general elections: Challenges of legislation and the future of electoral democracy in Nigeria [Poster presentation]. Political Conference 2019, Department of Political Science, Federal University, Lokoja, Nigeria.

Schmidt, V. (2006). Institutionalism. In C. Hay, M. Irster \& D, Marsh (Eds.), The State; theories and issues (Political Analysis) (pp. 98-118). Palgrave Macmillan.
Sears, A. (2008). A good book in theory: A guide to theoretical thinking. Higher Education University.

Taiwo, O. (2014, June 3). Nigerian assembly can summon oil minister without presidential consent. Africa Check. https://africacheck.org/ reports/nigerian-assembly-can-summon-oilminister-without-presidential-consent/

Umoru, H. (2018, July 8). Buhari government sent 12 bills to National Assembly in 3 years. Vanguard. https:/www.vanguardngr.com/2018/07/buharigovt-sent-12-bills-to-national-assembly-in-3years/

Wolff, S. (2006). Ethnic conflict: A global perspective. Oxford University Press.

Wright, J. G., \& McKeever, P. (2000). Qualitative research: Its role in clinical research. Annals of the Royal College of Physicians and Surgeons of Canada, 33, 275-280.

Yusuf, A. Y. (2018). The legislative functions and democratic consolidation in Nigeria 's Fourth Republic, 1999-2015 [Unpublished doctoral dissertation], Universiti Utara Malaysia. 